\title{
PEMBUATAN NANOPARTIKEL BERBASIS KITOSAN DARI INFUS DAUN SIRSAK (Annona Muricata LINN) SEBAGAI ANTIOKSIDAN
}

\author{
Yesi Desmiaty*, Deni Rahmat, Nilam Sari Maulidina \\ Fakultas Farmasi Universitas Pancasila \\ Srengseng Sawah, Jagakarsa, South Jakarta, 12460 \\ *E-mail: yesidesmiaty@ gmail.com
}

\begin{abstract}
ABSTRAK
Daun Sirsak (Annona muricata Linn), Annonaceae telah diketahui memiliki kemampuan meredam radikal bebas yang kuat dan bisa dikembangkan menjadi sediaan farmasi antioksidan. Pembentukan nanopartikel dari ekstrak akan meningkatkan stabilitas, kemampuan mukoadhesif dan penetrasi ekstrak sehingga dapat meningkatkan efektifitasnya. Pembuatan nanopartikel dilakukan dengan melarutkan kitosan dalam larutan asam asetat glasial 1\%, dan dicampurkan dengan infus daun sirsak. Suspensi nanopartikel ekstrak daun sirsak dikeringkan dengan menggunakan alat pengering semprot. Hasil evaluasi nanopartikel ekstrak diperoleh ukuran partikel $131,23 \pm 1,81 \%$, indeks polidispersitas $0,3-0,4$; padatan total $0,47 \%$, warna coklat muda, bau khas ekstrak, rasa pahit, sifat serbuk halus, higroskopis, kadar air $6.86 \pm 0,88 \%$. Pemeriksaan aktivitas antioksidan pada nanopartikel ekstrak daun sirsak dengan menggunakan metode peredaman radikal bebas DPPH menunjukkan aktivitas antioksidan kuat dengan nilai $1 C_{50}$ sebesar $80,98 \mathrm{bpj}$.
\end{abstract}

Kata kunci : daun sirsak, Annona muricata Linn., DPPH, antioksidan, nanopartikel, kitosan

\section{PENDAHULUAN}

Berbagai penyakit degeneratif seperti diabetes, kanker, inflamasi jaringan, kelainan imunitas, infark jantung dan penuaan dini disebabkan tingginya kadar radikal bebas dalam tubuh. Radikal bebas yang merusak tubuh ini dapat dinetralisir oleh senyawa antioksidan. Antioksidan merupakan senyawa yang dapat menghambat oksigen reaktif dan radikal bebas dalam tubuh. Senyawa antioksidan ini akan menyerahkan satu atau lebih elektron kepada radikal bebas sehingga menjadi bentuk molekul yang normal kembali dan menghentikan berbagai kerusakan yang ditimbulkan. Dalam studi laboratorium, kehadiran antioksidan eksogen telah terbukti untuk mencegah kerusakan radikal bebas yang telah dikaitkan dengan perkembangan kanker.

Tujuan pembuatan nanopartikel adalah sebagai pembawa (carrrier) agar zat berkhasiat dari ekstrak masuk ke dalam sistem peredaran darah tanpa kehilangan material aktif selama proses penghantaran untuk selanjutnya dibawa oleh darah menuju target pengobatan. Nanopartikel mempunyai ukuran di bawah 1 mikrometer sehingga dikenal dapat masuk kedalam sel dan memberikan aktivitas dan menunjukkan reprodisibilitas terapi yang baik. Selain itu, permukaan nanopartikel dapat dimodifikasi untuk sistem penargetan terhadap sel dan organ tertentu sehingga dapat menurunkan dosis dan toksisitasnya. Nanopartikel dpat tinggal di saluran cerna dalam waktu yang cukup lama sehingga dapat meningkatkan 
Pembuatan Nanopartikel Berbasis Kitosan dari Infus Daun Sirsak (Annona Muricata LINN) sebagai Antioksidan

bioavailabilitas dengan sifat mukoadhesifnya.

Berbagai bagian organ tanaman sirsak Annona muricata Linn. (Annonaceae) secara luas digunakan di dunia baik untuk manajemen, kontrol dan pengobatan sejumlah penyakit seperti antikonvulsan, anti-artritis, antiparasitik, antimalaria, hepatoprotektif dan aktivitas antidiabetes, termasuk antikanker (Moghadamtousi SZ, etc., 2015). Studi pustaka menunjukkan bahwa daun Anonna muricata (sirsak) memiliki aktivitas antioksidan lebih kuat dibandingkan dengan $A$. squamosa dan $A$. reticulata. (Baskar., Indian J Exp Biol, 2007). Dari penelitian sebelumnya telah dibuat ekstrak terstandar daun sirsak yang memiliki aktivitas antioksidan kuat (Desmiaty Y, 2015). Pada penelitian ini dibuat ekstrak infus daun sirsak kemudian ekstrak dienkapsulasi dengan teknologi nanopartikel. Nanopartikel yang mengandung ekstrak daun sirsak dijadikan serbuk kering dengan menggunakan pengering semprot. Untuk mengetahui aktivitas nanopartikel ekstrak daun sirsak secara in vitro, dilakukan pengujian aktivitas antioksidan terhadap ekstrak dengan menggunakan metode peredaman radikal bebas DPPH (1,1-difenil-2pikrilhidrazil).

\section{METODE}

\section{BAHAN}

Simplisia kering daun sirsak (Annona muricata L.), DPPH (1,1-difenil2-pikrilhidrazil), dan Kitosan (Biotech Surindo), Asam asetat glasial 1\% (Mallinckrodt)

\section{ALAT}

Alat pengering semprot (Bǘchi Mini Press-II), alat uji kadar air KarlFischer (Metrohm $870 \mathrm{KF}$ Titrino plus), Particle sizer DelsaNano ${ }^{\mathrm{TM}}$, dan alat uji kadar air Karl-Fischer (Metrohm 870 KF
Titrino plus), Alat uji distribusi ukuran partikel (Testing sieve TSUTSUI), Alat uji sifat alir (Granule flow tester Autonics LE35)

\section{METODE PENELITIAN}

1. Pengumpulan dan penyediaan bahan penelitian

Daun sirsak yang digunakan dalam penelitian ini diperoleh dari kebun balitro Cimanggu, Bogor dan dilakukan determinasi di Laboratorium Pusat Penelitian Biologi, Lembaga Ilmu Penelitian Indonesia, Cibinong

2. Pembuatan infus daun sirsak

Sebanyak $80 \mathrm{~g}$ simplisia daun sirsak dimasukkan ke dalam panci infus dan ditambahkan air sebanyak 1,6 L. Kemudian dipanaskan dalam tangas air selama 15 menit, dihitung mulai suhu di dalam panci mencapai $90^{\circ} \mathrm{C}$, sambil sesekali diaduk. Infus diserkai dengan kain flanel selagi masih panas. Infus dipekatkan dengan vacum rotavapor pada suhu penangas $50^{\circ} \mathrm{C}$, rotasi $60 \mathrm{rpm}$, tekanan dalam vakum $35 \mathrm{mmHg}$.

3. Pembuatan nanopartikel ekstrak daun sirsak dengan kitosan

Kitosan sebanyak 1 gram dilarutkan dalam $100 \mathrm{~mL}$ asam asetat glasial $1 \%$ menggunakan magnetik stirrer sehingga diperoleh konsentrasi kitosan $1 \%$. Sebanyak $500 \mathrm{mg}$ ekstrak daun sirsak dilarutkan dalam $135 \mathrm{~mL}$ aquadest, 10 $\mathrm{mL}$ etanol, dan $15 \mathrm{~mL}$ DMSO $1 \%$, kemudian disaring. Selanjutnya, ditambahkan larutan kitosan 1\% sebanyak $80 \mathrm{~mL}$ sehingga konsentrasi kitosan menjadi $0,3 \%$ dalam magnetik stirrer rpm 400 hingga terbentuk nanopartikel yang ditandai dengan kekeruhan yang homogen lalu tetap diatas magnetik stirrer selama 30 menit agar didapat larutan nanopartikel ekstrak daun sirsak yang stabil. Kemudian diamati kestabilan larutan nanopartikel ekstrak daun sirsak selama 5 hari yang meliputi warna, kekeruhan dan endapan.

4. Pemeriksaan ukuran dan distribusi partikel 
Pembuatan Nanopartikel Berbasis Kitosan dari Infus Daun Sirsak (Annona Muricata LINN) sebagai Antioksidan

Pemeriksaan ukuran dan distribusi partikel dengan menggunakan alat Particle sizer DelsaNano ${ }^{\mathrm{TM}}$

5. Penentuan bobot padatan total nanopartikel ekstrak daun sirsak

Sejumlah $20 \mathrm{~mL}$ suspensi nanopartikel ekstrak daun sirsak dimasukkan ke dalam cawan penguap yang telah dipanaskan sampai bobot tetap (W2), dimasukkan suspensi nanopartikel ekstrak daun sirsak, kemudian ditimbang. Selanjutnya suspensi nanopartikel dikeringkan dalam oven suhu $40^{\circ} \mathrm{C}$ sampai diperoleh bobot konstan (W1). Bobot padatan total dihitung dalam persen (\%), dengan perhitungan sebagai berikut:

$\%$ Padatan total $=\frac{\mathrm{w} 1-\mathrm{w} 2}{\mathrm{v}} \times 100 \%$

Keterangan $: \mathrm{W} 1=$ Bobot cawan + serbuk kering

W2 = Bobot cawan kosong

$\mathrm{V}=$ Volume suspensi nanopartikel

6. Pembuatan serbuk kering nanopartikel

ekstrak daun sirsak

Nanopartikel ekstrak daun sirsak dimasukkan ke dalam alat pengering semprot dengan suhu inlet $190^{\circ} \mathrm{C}$ dan suhu outlet $90^{\circ} \mathrm{C}$

7. Evaluasi serbuk kering nanopartikel

ekstrak daun sirsak, meliputi:

a. Pemeriksaan organoleptik

Pengujian dilakukan dengan melihat warna, bau, dan rasa dari serbuk kering nanopartikel ekstrak daun sirsak

b. Penetapan kadar air

Ditimbang lebih kurang $30 \mathrm{mg}$ serbuk kering nanopartikel ekstrak daun sirsak dan dimasukkan ke dalam alat moisturemeter Karl Fischer.

8. Pemeriksaan aktivitas antioksidan serbuk kering nanopartikel ekstrak daun sirsak dengan menggunakan metode peredaman radikal bebas DPPH. a. Pembuatan larutan DPPH $(0,4$ $\mathrm{mM}$ )

Ditimbang lebih kurang $8 \mathrm{mg}$ DPPH (1,1-difenil-2-pikrilhidrazil), kemudian dilarutkan dengan metanol pro analisis hingga $50,0 \mathrm{~mL}$, tempatkan dalam botol gelap.

b. Pembuatan larutan blangko

Dipipet $1 \mathrm{~mL}$ larutan $\mathrm{DPPH}$ $(0,4 \mathrm{mM})$ ke dalam labu tentukur 5,0 mL, kemudian ditambahkan metanol hingga tanda, lalu homogenkan.

c. Pembuatan larutan uji

Timbang 5,0 mg sampel kemudian dilarutkan dalam 5,0 mL metanol pro analisis (1000 bpj), larutan ini merupakan larutan induk. Dipipet $25,0 \mu \mathrm{L}$, $50,0 \mu \mathrm{L}, 125,0 \mu \mathrm{L}, 250,0 \mu \mathrm{L}$ dan $500,0 \mu \mathrm{L}$ larutan induk ke dalam labu tentukur 5,0 $\mathrm{mL}$ untuk mendapatkan konsentrasi sampel 5, 10, 25, 50 dan $100 \mu \mathrm{g} / \mathrm{mL}$. Ke dalam masing-masing labu tentukur ditambahkan 1,0 mL larutan DPPH dan ditambahkan dengan metanol pro analisis sampai tanda, kemudian dihomogenkan.

d. Pembuatan larutan vitamin C sebagai kontrol positif

Timbang 5,0 $\mathrm{mg}$ vitamin $\mathrm{C}$ kemudian dilarutkan dalam 5,0 $\mathrm{mL}$ metanol pro analisis (1000 bpj), larutan ini merupakan larutan induk. Dipipet $10,0 \mu \mathrm{L}$, $20,0 \mu \mathrm{L}, 30,0 \mu \mathrm{L}, \quad 40,0 \mu \mathrm{L}, \quad$ dan $\quad 50,0 \mu \mathrm{L}$ larutan induk ke dalam labu tentukur 5,0 $\mathrm{mL}$ untuk mendapatkan konsentrasi sampel 2, 4, 6, 8, dan $10 \mu \mathrm{g} / \mathrm{mL}$. Ke dalam masing-masing labu tentukur ditambahkan 1,0 mL larutan DPPH dan ditambahkan dengan metanol pro analisis sampai tanda, kemudian dihomogenkan.

e. Uji aktivitas antioksidan

Larutan uji dan kontrol positif dengan beberapa konsentrasi diinkubasi pada suhu $37^{\circ} \mathrm{C}$ selama tepat 30 menit, serapan diukur pada panjang gelombang maksimum $516 \mathrm{~nm}$ menggunakan spektrofotometri ultraviolet-cahaya tampak. 
Pembuatan Nanopartikel Berbasis Kitosan dari Infus Daun Sirsak (Annona Muricata LINN) sebagai Antioksidan

Persentase inhibisi dihitung menggunakan rumus sebagai berikut :

$\%$ hambatan $=\frac{\text { (serapan blanko-zerapan ampel) }}{\text { serapan blanko }} \times 100 \%$

\section{HASIL PENELITIAN}

Perhitungan nilai $\mathrm{IC}_{50}$ dengan memasukkan nilai dari konsentrasi larutan uji (sumbu $x$ ) dan persen hambatan terhadap DPPH (sumbu y) kedalam persamaan garis regresi.

\section{EVALUASI NANOPARTIKEL}

Diamati kestabilan larutan nanopartikel ekstrak daun sirsak selama 5 hari yang meliputi warna, kekeruhan dan endapan.

Tabel 1. Hasil pengamatan larutan nanopartikel ekstrak daun sirsak

\begin{tabular}{cccccc}
\hline Parameter & Hari ke-1 & Hari ke-2 & Hari ke-3 & Hari ke-4 & Hari ke-5 \\
\hline Warna & Coklat muda & Coklat muda & Coklat muda & Coklat muda & Coklat muda \\
Kekeruhan & Stabil & Stabil & Stabil & Stabil & Stabil \\
Endapan & Tidak ada & Tidak ada & Tidak ada & Tidak ada & Tidak ada \\
\hline
\end{tabular}

Tabel 2 Hasil uji pemeriksaan serbuk nanopartikel ekstrak daun sirsak

\begin{tabular}{ccc}
\hline No & Uji & Hasil \\
\hline 1 & pemeriksaan ukuran partikel & $131,23 \pm 1,81 \%$ \\
2 & Indeks Polidispersitas & $0,3-0,4$ \\
3 & \% padatan total & $0,47 \%$ \\
4 & Warna & Coklat muda \\
5 & Bau & Khas ekstrak \\
6 & Rasa & Pahit \\
7 & Sifat serbuk & Halus, higroskopis \\
8 & Kadar air & $6.86 \pm 0,88 \%$ \\
\hline
\end{tabular}

Suatu larutan nanopartikel dikatakan memiliki ukuran nanopartikel jika diameter berukuran 10-1000 nm. Data hasil uji pemeriksaan ukuran partikel pada larutan nanopartikel ekstrak daun sirsak menunjukkan ukuran partikel yang memenuhi syarat ukuran nanopartikel yaitu $131,23 \pm 1,81 \%$. Metode pembuatan yang digunakan mempengaruhi hasil yang didapat, pada penelitian ini digunakan metode gelasi ionik dengan pengaduk magnetik sehingga didapat larutan dengan ukuran partikel yang kecil dan homogen.
Distribusi ukuran partikel dinyatakan dalam indeks polidispersitas dengan rentang nilai $0-1$. Bila nilai indeks mendekati 0 menunjukkan disperse homogen sedangkan bila indeks lebih dari 0,5 menunjukkan heterogenitas yang tinggi. Hasil pengujian menunjukkan suspensi nanopartikel yang ekstrak daun sirsak memiliki disperse yang relatif homogen.

Perhitungan padatan total bertujuan untuk mengetahui dosis serbuk kering nanopartikel ekstrak daun sirsak yang dibutuhkan untuk 1x pakai. 
Pembuatan Nanopartikel Berbasis Kitosan dari Infus Daun Sirsak (Annona Muricata LINN) sebagai Antioksidan

Berdasarkan hasil dari pengeringan semprot suspensi nanopartikel, didapatkan berupa serbuk halus, higroskopis yang berwarna coklat muda, berbau khas ekstrak dan memiliki rasa yang pahit. Pemeriksaan kadar air serbuk kering nanopartikel ekstrak daun sirsak didapat kadar air rata-rata 6,86\%. Kadar air ini memenuhi syarat kadar air untuk bahan alam.

\section{UJI AKTIVITAS ANTIOKSIDAN}

Aktivitas antioksidan diketahui dari nilai serapan beberapa konsentrasi sampel setelah direaksikan dengan larutan radikal bebas DPPH. Semakin rendah nilai $I C_{50}$ berarti semakin tinggi aktivitas antioksidan sebagai peredam radikal bebas.

Tabel 3 Hasil uji aktivitas antioksidan

\begin{tabular}{lll}
\hline \multicolumn{1}{c}{ Sampel } & \multicolumn{1}{c}{ Nilai } \\
& $\boldsymbol{I C}_{\mathbf{5 0}(\mathbf{b p j})}$ \\
\hline Vitamin C & 6,77 \\
$\begin{array}{l}\text { Nanopartikel } \\
\text { daun sirsak }\end{array}$ & ekstrak & 80,98 \\
\hline
\end{tabular}
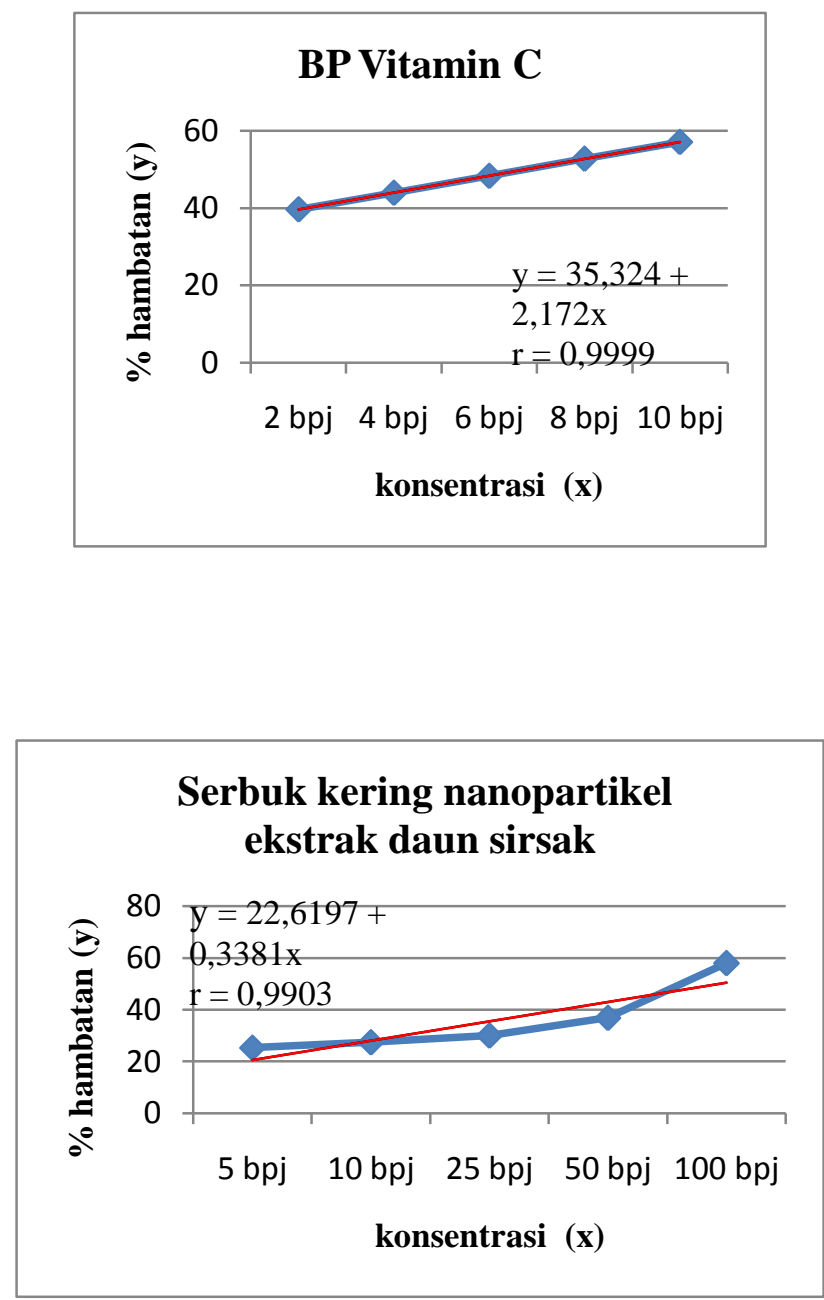

Gambar 1. Grafik hubungan antara konsentrasi (x) dan \% hambatan (y) pada BP Vitamin C dan serbuk nanopartikel ekstrak daun sirsak. 


\section{KESIMPULAN}

1. Ekstrak infus daun sirsak dapat dibuat nanopartikel dengan ukuran partikel yang memenuhi syarat ukuran yaitu $131,23 \pm 1,81 \%$, Indeks Polidispersitas $0,3-0,4$; padatan total $0,47 \%$, Warna Coklat muda, Bau Khas ekstrak, Rasa Pahit, Sifat serbuk Halus, higroskopis, Kadar air $6.86 \pm$ $0,88 \%$

2. Nanopartikel ekstrak daun sirsak menunjukkan aktivitas antioksidan kuat dengan nilai $1 C_{50}$ sebesar 80,98 bpj.

\section{UCAPAN TERIMAKASIH}

Penelitian ini didanai oleh Hibah Bersaing Ristek Dikti 2015.

\section{DAFTAR PUSTAKA}

1. Moghadamtousi SZ, Fadaeinasab M, Nikzad S, Mohan G, Ali HM, Kadir HA, Annona muricata (Annonaceae): A Review of Its Traditional Uses, Isolated Acetogenins and Biological Activities., Int J Mol Sci. $2015 \mathrm{Jul}$ 10;16(7):15625-58.
2. Desmiaty Y., Rahmat D., Sari Maulidina N., Preparation of Standardized Aqueous Extract of Annona Muricata Linn. Leaf, Its Potency as Antioxidant, and Total Flavonoid Content Assay, Proceeding International Seminar of POKJANAS TOI $49^{\text {th }}$, Jakarta, 2015.

3. S Adewole, J Ojewole, Protective effects of Annona muricata linn. (Annonaceae) leaf aqueous extract on serum lipid profiles and oxidative stress in hepatocytes of streptozotocin-treated diabetic rats, African Journal of Traditional, Complementary and Alternative Medicines. Vol 6, No 1 (2009) ISSN: 0189-6016

4. Marisi R, Desmiaty, Y, Wida K. Uji pendahuluan aktivitas sitotoksik dan antioksidan ekstrak etanol daun sirsak (Annona muricata L.) dan batang brotowali (Tinospora crispa). Seminar Nasional POKJANAS TOI XLII- 2012.

5. Baskar R, Rajeswari V, Kumar TS., In vitro antioxidant studies in leaves of Annona species, Indian J Exp Biol. 2007 May;45(5):480-5. 